\title{
Beneficial Owner Rights in Nominee Agreement
}

\author{
Alfian Nanung Pradana \\ Mulyanto \\ SebelasMaret University \\ Surakarta, Indonesia
}

\begin{abstract}
Rights of Beneficial Owner in Nominee Agreement. Nominee Agreement has been used in many legal action in Indonesia, such as land case and company. The research aimed to know detail about Nominee Agreement. In addition, to know rights of one side party in Nominee Agreement, that is beneficial owner. The research has normative juridicially characteristic. The approach methods that used were conceptual and regulation approach. The results explain that Nominee Agreement includes one of innomiaat agreement, and the beneficial owner has a right to obtain benefits of his property that was bought, but he does not has fully right to do legal action over that property.
\end{abstract}

Keywords: agreement, nominee, beneficial owner.

\section{Introduction}

In each country on the whole word always attempts to create a wealth for its citizen with develop in every sector. To implement those, the countries must give support to sectors that can be drive country development, both government and private sectors. Therefore, it need investment of any parties for supporting the country development.

Indonesia is a developing country has many potentions that interesting many investors both local and foreign for investment in Indonesia(Margono, 2008, p. 2). It's been used for supporting nation and country development in economy sector. National economy development has been implemented based on economy democration with collective principle, fairly efficient, suitainable, environment viewed, autonomy and keeping balance of progress, and national economy united to create citizen wealth. There are some significant factors that evoke the investment climate develop in Indonesia as investor's intentions, as follows:

1. Regulation or policy that support foreign investors to give their capital in Indonesia.

2. Enormous workers with low budget.

3. Wide market production because of enourmous Indonesian people

4. Resources are available

5.Political stability

6. legal certainty and consistency of regulations and its application(Pramono, 2006, p. 173).

However, beside from some of the positive things mentioned above, sometimes investors also experience a conflict with the law in Indonesia when they will invest their capital in Indonesia, especially foreign investors or investors who are not Indonesian citizens. Foreign investors who are interested in direct investment in Indonesia are obstructed by the negative list investment rules contained in the Republic of Indonesia's Presidential Regulation No. 39 of 2014 concerning List of General and Private Business Sectors with requirements of Capital investment. The Government, in this case the Investment Coordinating Board, prohibits foreign investors from investing in order to provide protection to the lives of the Indonesian people. Some business sectors that are included in the negative list investment include the production of weapons, gunpowder, explosive devices, war equipment, and so on.

In addition to this, another example is that foreign citizens may not have ownership rights to land in Indonesia, as stipulated in Article 21 paragraph (1) of Law number 5 of 1960 concerning Basic Regulations on Agrarian Principles, which states that "only Indonesian citizens who can have ownership rights ". Because of this, to accommodate the needs of both parties, Foreign Citizens who want to invest in developing countries such as Indonesia, and our own country that needs fresh funding from abroad, an agreement that we are familiar with is nominee.

Basically, the agreement can be a Nominaat Agreement and Innominaat Agreement. Nominate Agreement is a named agreement as contained in Article 1319 of the Civil Code, such as Sale and Purchase, lease, accounts payable and so forth, and the Innominaat Agreement, which is a Agreement that is not clearly stated in the Civil Code but grows, lives, and develops in the community(Salim, 2003, p. 47). The Nominee Agreement of its structure is included in the Innominaat agreement because it is not regulated in the Civil Code but grows from the needs of the community. 
In fact, there are many Nominee agreements between the foreigners and Indonesian citizens in terms of foreigners wanting to own assets or build a business in Indonesia. The concept of nominee or sometimes called the concept of trust is unknown in the civil law system that prevails in Indonesia. Trusts which at first were said to be typical of common law legal traditions, along with the flow of investment, around the 90s in Indonesia began to recognize the concept of nominees and were often used in several legal transactions(Widjaja, 2013, p. 18). Nominee Agreement in this context, a citizen as a legal owner (Nominee), his name is used by other parties who are usually Foreign Citizens or foreigners, as the actual beneficial owner of the land and / or building, or shares of a company in Indonesia.

Beneficial Ownership, or Top Owner, is the individual who gets the most benefit from business activities such as royalties, dividends, interest and so on. In this case, the beneficial owner, who is mostly a Foreign Citizen, can be said to be the true owner of the assets he has bought, even though he uses the name of an Indonesian citizen to purchase or invest his capital in Indonesia. However, in Indonesia there is evidence to seek and realize formal truth, which of course is the owner listed in possession of an asset or property is an Indonesian citizen, or nominee. Because of this, how exactly are the rights possessed by the beneficial owner in the nominee agreement?

\section{Research Methods}

This research method is the most important part of a research, because the research method will be the guide and direction for a research(Achmad, 2010, p. 104).This form of research is normative juridical. Based on the subject matter, the type of research to be conducted is the type of normative legal research, which is examined only library materials or secondary data, which may include primary, secondary and tertiary legal materials. This research is a descriptive study. Descriptive investigation aimed at solving existing problems in the present(Surakhmad, 1990, p. 139).

The research approach that I use is the conceptual approach and the statue approach. The materials used are:

a. Primary legal materials includes:

1) Republic of Indonesia 1945 Constitution;

2) Civil Code;

3) Law Number 5 of 1960 concerning Basic Regulations on Agrarian Principles;

4) Law Number 4 of 1996 concerning Security Rights and Land Related Items;

5) Law No. 25 of 2007 concerning Investment;

6) Law No.40 of 2007, concerning Limited Liability Companies;

7) Government Regulation Number 24 of 1997 concerning Land Registration;

8) Presidential Regulation Number 39 Year 2014 concerning List of Private and General Business Sectors with Its Requirements.

b. Secondary legal material consists of books, literature, research results, papers, and electronic newspapers.

Furthermore, the data analysis method that will be used in this study is data analysis so that the form of the results of this study is descriptive analytical explaining the nominee agreement, and the beneficial owner's rights in the nominee agreement.

\section{Results and Analysis}

Basically, there are no laws and regulations in Indonesia that regulate and explain in detail what is a nominee agreement. That is because the nominee agreement is one of the innominate agreements, agreements that are not clearly stated in the Civil Code but exist, live, and develop in the community. Therefore, all matters regarding nominees have no legal rules that stipulated with certainty, and explain rigidly about the provisions in nominee agreements.

In general, nominees can be interpreted as follows: one who has been nominated to an office or for a candidacy, a person organization in whose name a security is registered even though true ownership is held by another party. Another definition given by the dictionary in relation to a business transaction using the nominee concept is "person or firm into whose name securities or other properties are transferred in order to facilitate transactions, while leaving the customer as the actual owner. The definition of nominees may be drawn as a party appointed by another party to act on behalf of and on behalf of the party that refer the nominee.

Nominees are also closely related to realty trust or nominal trust, and nominal trust is a passive trust which has the definition of "A trust which he trustee has no other duty than to transfer the property to the beneficiary"(Gamer, 2008, p. 107). From the understanding given about the nominee it can be seen that literally, nominee, has two different meanings. First, nominee refers to a proposal, or nomination of a candidate to occupy a certain position, to obtain a certain award, or for other types of nominations. Second, the nominee provides understanding as someone who represents the interests of other parties. 
In this second sense, a nominee is distinguished from an authority in circumstances; where the nominee is the owner of an object (including interests or rights that emerged of an agreement) that is in its administration; whereas the power of attorney has never been the owner of the objects (including his interests) that are managed by this nominee(Widjaja, 2008, p. 43).

From the explanations above, it can be concluded that the Nominee Agreement is a name loan agreement made by two legal subjects which is the development of an Innominaate agreement or an unnamed agreement. Then it can be seen that in the nominee concept two parties are known, the nominee party that is legally registered and the beneficiary who enjoys every benefit and profit from the actions carried out by the party that is legally registered.

The existence of two parties in a nominee agreement incurres to two types of ownership, registered and legal owner (juridischeeigendom) and beneficial owner (economischeeigendom) obtaining the benefits and losses arising from objects owned by the nominee(Pramono N. , 2013, p. 395).

De jure, a nominee is the legal right holder of the object, which of course has the right to transfer, sell, burden, guarantee and take any action on the object related. Whereas de facto, the real owner or who buys an asset which is the object of the agreement is the beneficial owner. The term Beneficial Owner was first introduced in 1977 OECD Model Tax Convention Article 10 (Dividend), 11 (Interest) and 12 (royalty), in an effort to provide clear limits on parties that can be considered as recipients of lower tax rate facilities in the country sources of dividend income, interest and royalties.

A nominee agreements can also be associated with elements of belief, or trust. The common law system's view of trust is, "trusts is created the absolute owner of property (the settlor) passes the legal title in that property to a person (the trustee) to hold that property on trust for the benefit of another person (the beneficiary) in accordance with the terms set out by the settlor ". This implies that trust is made the absolute owner of the property (settlor) through the legal process of the property for someone (trustee) to hold the existing property in the trust for the benefit of others (recipients) in accordance with the conditions set by the absolute owner of the property or assets other.

Theoretically, in a statement of trusts, settlors or beneficial owners submit an object to be placed in trusts that are registered in the name or in the ownership of the trustee or nominee. It's shows that the beneficiary as the giver of an object, after the statement of trusts spoken by it is implemented de jure is no longer in control, has any interest in the object that has been submitted in the trusts. Beneficiary does not have the authority in law to demand fulfillment of trustee or nominee obligations. This explanation shows that a trustee or nominee is a party that has authority over the objects in the trusts, which are part of its obligations to the beneficiary or trust que, even though the authority is limited to the recording and registration of the trustee or nominee.

Practically in Indonesia, nominee agreements can be divided into two, direct and indirect nominees. Formation of nominees is directly formed by making and signing nominee agreements between beneficiaries and nominees in one agreement. The agreement is decisive and clearly stipulates the granting of trust and authority from the beneficiary to the nominee to carry out certain activities or business on the orders and interests of the beneficiary. In the ownership of shares by foreign parties who use the nominee concept, in general the names and identities of those registered as legal owners in the register of company shareholders are only the names and identities of nominees. The name and identity of the beneficiary does not appear in any form whatsoever on the list of company shareholders. By using the name and identity of the nominee as a legally registered party, the beneficiary provides compensation in the form of nominee fees. The amount of the nominee fee is based on mutual agreement between the nominee and the beneficiary.

After reaching a mutual agreement, the amount and procedure for payment of the nominee fee will be stated in the form of a written agreement signed by the nominee and beneficiary as a form of agreement. The characteristics of the use of the stock nominee concept include:

a. there are 2 types of ownership, legal ownership (juridischeeigendom) and benefit (economischeeigendom);

b. nominee name and identity will be registered as the owner of shares in the Register of Company Shareholders in nominee share ownership;

c. nominee receives a fee in a certain amount as compensation for the use of his name and identity for beneficiary's interests.

Thus, it can be seen that the structure used in the nominee concept is the existence of agreements made by and between nominees and beneficiaries, known as nominee agreements. Nominee and beneficiary will determine what matters will be stated in the nominee agreement. In the agreement, besides regulating the amount and procedure for payment of nominee fees, it will also regulate the provisions that require and / or prohibit nominees from doing anything related to use the nominee concept. 
Whereas nominees are not directly formed from nominee agreements which expressly and clearly give trust and authority from the beneficiary to the nominees. Indirect nominees do not consist of only one agreement, but rather consist of several agreements which, if connected to one another, will produce a share nominee. The beneficiary can control nominees to carry out certain business actions or activities on the orders and interests of the beneficiary.

The deeds which are made both notary and underhand are as follows:

a. Loan Agreement Deed;

b. Pledge of Share Agreement;

c. Indemnity Agreement;

d. Power of Attorney to Vote;

e. Sale and Purchase of Shares and Purchase of Sale (Attorney to Sell Shares) Agreement.

When be seen from these deeds it can be concluded that the nominee as the actual shareholder in the law does not have the authority to exercise the inherent rights of the shares held in the limited company because it has been submitted to the beneficiary. But in reality, legally, nominee shareholders are authorized to exercise the rights to the shares they hold.

Formation of nominee agreements through direct and indirect nominees formation have the same goals or achievements to produce share nominees in Indonesia. The goals or achievements to be obtained are:

a. beneficiary as controller of shares and nominees is as registered owner;

b. the source of funds used comes from beneficiaries but is made as if it was beneficiary loans to nominees;

c. the rights of shares owned by the nominee are lost, so that beneficiaries who have the right to sell, transfer, take over the shares;

d. beneficiary receives benefits from these shares in the form of dividends and other benefits.

Nominee agreements are often used in Indonesia in various sectors, among which the most common uses of nominee agreements are in the land and company. In the land sector, nominee agreements are often found where the beneficial owner is a Foreign Citizen and the nominee is an Indonesian citizen. This is because in the statutory provisions of Indonesian Foreign Citizens are not allowed to have ownership rights to land in Indonesia. Meanwhile, many foreigners who want to buy land in Indonesia are related to investing or establishing a business. Therefore, the middle ground of this problem was taken, by making a nominee agreement.

The term nominee is often equated with the term representative or borrowed name, which is based on the statement letter or power of attorney made by the parties, said that foreigners borrow the name of an Indonesian citizen to include his name as the owner of the land in his certificate. But then an Indonesian citizen based on the deed he made denied that the real owner was a foreign citizen as the party who issued the money to purchase the land and his control was exercised or represented by the foreign national.

Implicitly, a nominee agreement has the following elements:

1. There is an agreement between the two parties giving power of attorney, the beneficial owner as the principal and the nominee as the attorney, based on the trust of the beneficial owner to the nominee.

2. The power of attorney is special with limited types of legal action

3. Nominees act as if (as If) as representatives of the beneficial owner viewed by the law.

At first glance it can be seen that the nominee agreement with the granting of power is generally the same because both of them require the parties acting as the principal and the attorney. However, if examined carefully, both are similar but not the same thing. Nominee agreements are of the same nature as mutual agreements, where the parties have an obligation to fulfill the achievements of each party listed in the agreement. This is due to the power contained in the nominee agreement is more lastgeving, where the power given is more emphasis on giving the burden of orders to the recipient to carry out the promised achievements. The authorizer/principal which is generally made is a unilateral agreement that is volmacht because it only gives authority to the recipient to represent the authorizer. This concept is regulated by the mechanism that the owner of the house or building is an Indonesian citizen with costs sourced from the foreign national. The ownership referred to is an indirect ownership, which is created from the legal relationship between the Indonesian citizen and the foreign national connected in an agreement called the Nominee / Trustee Agreement, where the agreement contains a statement of legal relationship between the Indonesian citizen and the foreigner stating that ownership of rights to The land is basically the property of the concerned Indonesian citizen and foreign national who can order various legal actions against the rights "owned" by foreigners who are trusted to manage it (trustee). In general, the Nominee agreement consists of a Master Agreement which consists of a Land Ownership Agreement and a Power of Attorney; Option Agreement; Lease Agreement; Power of Attorney to Sell; Testamentary and Statement of Heirs(Sumardjono, 2005, p. 14). 
Such an agreement was made possible because basically it did not transfer ownership rights directly, but only transferred institutional land rights (ownership and building use rights). Therefore, de jure or juridical, the owner of the land is an Indonesian citizen as a nominee. Because of this, the Indonesian citizen, who has the authority to take care of everything related to the land, either transfers in the form of selling or renting, or putting up a mortgage on the land which is the object of the nominee agreement. This is because according to Article 4 of the Government Regulation of the Republic of Indonesia Number 24 of 1997 Concerning Land Registration, to provide legal certainty, land title holders are given certificates. And in the case of nominee agreements, those registered are in the nominee's name. Then, the beneficial owner does not have juridical authority to carry out legal actions against the land, but can get enjoyment related to the benefits obtained from the land as stated and agreed in the nominee agreement.

While in relation to companies, which are also nominee agreements, there are similarities with the nominee agreements described above, that de jure or juridical owners who are legally recognized are nominee parties or whose names are used. In a nominee agreement, the existence of a person or a certain party (nominee) is used as a shareholder or more precisely the registered owner of a certain number of shares, while the beneficiary gets benefits from these shares. The purpose of this nominee agreement is intended to hide the ownership of beneficiary shares to the general public and eliminate affiliated relationships between one company and other companies that already exist or were established earlier.

And in Act No. 40 of 2007 concerning the Company, Article 75 explains that it is the Shareholders who are entitled to take responsibility at the General Meeting of Shareholders, and also in making decisions, as explained below:

Paragraph (1) of RUPS has authority that not granted to the Directors or Board of Commissioners, within the limits specified in this Law and / or articles of association. Paragraph (2) In the RUPS forum, shareholders are entitled to obtain information relating to the Company from the Board of Directors and / or the Board of Commissioners, as long as it is related to the agenda of the meeting and does not conflict with the interests of the Company. Paragraph (3) of RUPS in other agenda items is not entitled to make a decision, unless all shareholders are present and / or represented in RUPS and approve the addition of the agenda item. Paragraph (4) Decisions on added agenda items must fully approved.

From Article 75 of Law number 40 of 2007, it can be explained that shareholders can vote at the General Meeting of Shareholders. If a nominee agreement is used, the name written in the shareholders is the nominee, not the legal owner. Therefore, the beneficial owner has no right or no voting rights in the GMS. However, as in the case of the land above, the beneficial owner can enjoy the benefits of the profits obtained by the company in accordance with what was agreed in the nominee agreement.

In terms of nominees, losses incurred as a result of decisions made by beneficiaries in the management of shares, voting in RUPS or other legal consequences incurred from the decision, before the nominee law as the party responsible. This is because the nominee as the legal owner of the shares. The responsibility of the beneficiary to bear the losses suffered by the nominee cannot be forced in front of the law.

That is the concept of a nominee agreement in a company. However, nominee agreements relating to this company law do not apply. As stipulated in Law number 25 of 2007 concerning Foreign Investment Article 33 paragraph (1), which states:

"Domestic investors and foreign investors who make investments in the form of limited liability companies are prohibited from making agreements and / or statements confirming that the ownership of shares in the company is limited to and on behalf of others."

In addition, in Article 48 paragraph (1) of Law no. 40 of 2007 concerning Limited Liability Companies also expressly stipulates that shares are issued in the name of the owner. So, the shares are mandatory on behalf of the shareholders, the names of shareholders cannot be different from the real owner.

As explained above, in particular the provisions of Article 33 paragraph (1) and paragraph (2) of UUPM, domestic investors and foreign investors are prohibited from making agreements and / or statements confirming that ownership of shares in a company is limited to and on behalf of others. If there is such an agreement, then the agreement is declared null and void. So, there is no legal way to guarantee that the shareholder whose name is borrowed will resell his shares to the actual shareholders (investors). This is because the structure of nominee arrangements is prohibited in our laws and regulations.Law No. 40 of 2007 concerning Limited Liability Companies in Article 52 paragraph (4) and Article 60 paragraph (4) apply to the concept of ownership of the shares completely or fully (dominium plenum).

So there is no division between benefit ownership of shares or share ownership registered by other parties, so that the shares of a company are a unified whole including rights attached to the shares themselves such as voting rights. The voting rights in the shares remain with the shareholders (their owners). 
So based on the above regulations, the concept of nominees is not allowed in matters relating to the company. Therefore, there is no right from the beneficial owner in relation to the company.

\section{Conclusion}

A nominee agreement or name loan agreement includes in the inominaat agreement, where this agreement is not clearly stated in the Civil Code but grows, lives, and develops in the community. The basic concept of a nominee agreement is where there is a legal subject that acts as a beneficial owner, the party who has capital or funds to buy an asset, and also the party who is a nominee, that is the party whose name is used to purchase and own the asset.

The beneficial owner in the case of land does not have any rights in the eyes of the assets purchased, because in the formal proof of ownership of the asset above the name is nominee. However, the beneficial owner can also gain benefit from the results of the assets purchased as agreed in the nominee agreement. While in companies, domestic investors and foreign investors are prohibited from making agreements and / or statements that confirm that the ownership of shares in the company is limited to and on behalf of others. If there is such an agreement, then the agreement is declared null and void.

Suggestions from the author, in order to be regulated further in legal products regarding the nominee agreement. This aims to have legal certainty, regarding what are the rights and obligations of each party in the nominee agreement.

\section{Bibliography}

Achmad, Yulianto and FajarMukti. (2010). DualismePenelitianHukum. Yogyakarta: PustakaPelajar.

Gamer, B. A. (2008).Law Dictionary. St. Paul: West.

Margono, Sujud. (2008).HukumInvestasiAsing di Indonesia. Jakarta: NovindoPustakaMandiri.

Pramono, Nindyo. (2006). HukumBisnisAktual. Bandung: Citra Aditya Bakti.

Pramono, Nindyo. (2013). Hukum PT danPasar Modal. Yogyakarta: Andi.

Salim, H. S. (2003). HukumKontrakdanTeknikPenyusunanKontrak. Jakarta: SinarGrafika.

Sumardjono, Maria. (2005). KebijakanPertanahan Antara RegulasidanImplementasi. Jakarta: Kompas.

Surakhmad, Winarno. (1990).PengantarPenelitianIlmiah. Bandung: Tarsito.

Widjaja, Gunawan. (2008). Nominee Stakeholder DalamPerspektif UUPT dan UU PMA.JurnalHukumdanPasar Modal.Volume III.

Widjaja, Gunawan. (2013). PentingnyaPengaturandalamInstitusi Di LuarPasar Modal.HimpunanHukumPasar Modal 